\title{
Childhood Giant Cell Glioblastoma
}

National Cancer Institute

\section{Source}

National Cancer Institute. Childhood Giant Cell Glioblastoma. NCI Thesaurus. Code

C114966.

A giant cell glioblastoma that occurs during childhood. 